\title{
CHRYSOMPHALUS AONIDUM(LINNAEUS, 1758), A NEW ALIEN PEST OF ORNAMENTAL PLANTS IN THE CZECH REPUBLIC (HEMIPTERA: COCCOIDEA: DIASPIDIDAE)
}

\author{
I. Hlavjenková, H. Šefrová
}

Received: April 5, 2012

\begin{abstract}
HLAVJENKOVÁ I., ŠEFROVÁ H.: Chrysomphalus aonidum (Linnaeus, 1758), a new alien pest of ornamental plants in the Czech Republic (Hemiptera: Coccoidea: Diaspididae). Acta univ. agric. et silvic. Mendel. Brun., 2012, LX, No. 5, pp. 69-78

First records of the alien species Chrysomphalus aonidum (Linnaeus, 1758) (Diaspididae) on ornamental plants in the Czech Republic are described. The species was registered in 2008-2010, on plants of Dracaena reflexa var. angustifolia (sold under the names of Dracaena marginata "Bicolor" and D. marginata "Tricolor") in garden centres of northern and southern Moravia (Opava, Ostrava, Brno). It was also found on two specimens of the same plant in households (Brno, Ostrava). Chrysomphalus aonidum had been occasionally introduced into the Czech Republic with citrus fruits formerly, but it had not been found on cultivated plants. Basic information on the morphology, diagnostic characters, biology, ecological requirements, host plants, geographical origin and distribution of this species is summarized, based on a review of relevant publications. Diagnostic characters are also figured. Economic importance and possibilities for control of this new pest are discussed.
\end{abstract}

alien species, Sternorrhyncha, armoured scale insects, houseplants, plant protection

The scale insect family Diaspididae (Hemiptera: Sternorrhyncha: Coccoidea), also known as armoured scale insects, includes a number of important pests of wild and greenhouse plants (Lindinger, 1912; Miller, 1956; Alford, 2002, 2007). The Diaspididae fauna of the Czech Republic was treated in several papers by Zahradník (1959, 1968, 1977, 1990). There are 56 species known from the country (Zahradník, 1977, 1990; Březíková 2005), of which 26 species were introduced from warmer regions of the world and their occurrence is restricted here mainly or exclusively to tempered spaces (Šefrová \& Laštůvka, 2005). This number does not include species occasionally introduced with southern fruits and not reproducing in the Czech Republic (six species; Zahradník, 1959). Increasing transport of various materials and live plants carries the risk of introduction of other exotic species of this family which may then become major pests of greenhouse and house plants.
The genus Chrysomphalus Ashmead, 1880 includes 17 species worldwide, five of which were found in Europe: Ch. pinnulifer (Maskel, 1891), Ch. diversicolor (Green, 1923), Ch. dictyospermi (Morgan, 1889), Ch. bifasciculatus Ferris, 1938 and Ch. aonidum (Linnaeus, 1758) (Ben-Dov, 2012). Zahradník (1968, 1977, 1990) mentions only one species, Chrysomphalus dictyospermi from central European greenhouses. Specimens of Chrysomphalus aonidum (cited as Chrysomphalus ficus Ashmead, 1880) were previously occasionally imported into central Europe on citrus fruits, but the species had not been detected in greenhouses (Zahradník, 1959).

This paper reports on first findings of reproducing populations of Chrysomphalus aonidum in the Czech Republic. Relevant publications dealing with this species are reviewed and general information on its reproduction, development, host plants, geographical distribution, and possibilities for control is provided. 


\section{MATERIALS AND METHODS}

Specimens of Chrysomphalus aonidum were collected from plants of Dracaena reflexa var. angustifolia (commonly available in the Czech Republic under the names of Dracaena marginata 'Bicolor' and D. marginata 'Tricolor') in garden centres and households in northern and southern Moravia (Opava, Ostrava, Brno) in 2008-2010. The samples were stored in $70 \%$ ethanol; some plants were taken into laboratory to observe the development of Ch. aonidum. The species was determined based on microscopic slides of adult females, prepared using a modified procedure by Martin (1987). The determination of adults was performed under microscopic magnification $10 \times 10$ or $10 \times 20$. The method involves a thermal maceration, removal of wax and dyeing with acid fuchsine. Coloured female bodies were then mounted in a synthetic resin (Solacryl). Photographs were prepared using a digital camera mounted on a stereomicroscope. Diagnostic characters were selected based on Miller \& Davidson (2005). The identification was kindly confirmed by Dr. Gillian Watson, specialist in the family Diaspididae (Plant Pest Diagnostics Branch, California Department of Food \& Agriculture, Sacramento, USA).

\section{RESULTS AND DISCUSSION}

\section{Chrysomphalus aonidum (Linnaeus, 1758) - material examined and finding circumstances}

Material examined: Czech Republic, Moravia bor., Opava, Globus Supermarket (field code number in the grid for mapping central European flora and fauna, e.g. Pruner \& Míka, 1996: 6073), 31.vii.2009; OBI Garden centre (6073), 4.viii.2009, 19.vii.2010; Ostrava, OBI Garden centre (6175), 10.vi.2010; Moravia mer., Brno, Globus Supermarket (6765), 30.xi.2008, 21.i.2010, 13.v.2010; Brno, household (6765), 19.xi.2008; Brno, Komárov, Baumax Garden centre (6865), 15.v.2010. All records comprising a few larvae and females on Dracaena reflexa var. angustifolia (=Dracaena marginata "Bicolor" and D. marginata "Tricolor"), I. Hlavjenková lgt. et det. Ten slide preparations of females are deposited in the collection of the Department of Crop Science, Breeding and Plant Medicine, Mendel University in Brno.

The first infested plant was brought from a household in Brno on 19.xi.2008. It was covered with honeydew and wax fiber clumps of Pseudococcus longispinus (Targioni \& Tozzetti, 1867) (Hemiptera: Coccoidea: Pseudococcidae). Larvae and females of Ch. aonidum occurred between the wax fibers. Larvae and females of Ch. aonidum were later found in garden centres of several cities, always on Dracaena reflexa var. angustifolia, as stated in the material examined section. The specimens were not immediately apparent and easily escaped attention. No distinct damage was observed on plants.

\section{Morphology and diagnostic characters}

The morphology of Ch. aonidum was described in detail by Schmutterer (1959), MacFarlane (1999), Miller \& Davidson (2005), Stahas \& Kozar (2005), and Watson (2005). Adult female cover is $1.5-2.5 \mathrm{~mm}$ wide, slightly convex, circular, dark brown, black or reddish brown. Shed skins are central, lighter than scale produced by adult, reddish yellow (Fig. 1). The adult female cover size depends on the host plant (2-2.5 mm on leaves of citrus, $2.0-2.2 \mathrm{~mm}$ on Ficus benjamina, and $1.3-1.7 \mathrm{~mm}$ on Ligustrum japonicum) (Stahas \& Kozar, 2005).

Female body is first pale yellow, later darker, with a light pygidium, pear-shaped, rounded anteriorly, elongate posterior to mesothorax, with a prominent thoracic tubercle (Fig. 2). Adult female body size is 1.1-1.7 mm. Before oviposition, the body is slightly elongated along its axis. During oviposition, it is becoming more rounded and the pygidium appears closer to the rest of the body. After removing the cover, the ventral part of the female body remains in contact with the host plant epidermis.

Male cover is slightly elongate, about $0.6-1.0 \mathrm{~mm}$ long, dark chestnut-coloured, with apex located excentrically. Exuviae are light brown, located submarginally, closer to one edge, about in the middle of the front plate. Adult males are about $0.8 \mathrm{~mm}$ long, orange-yellow, winged, and shortlived.

Miller \& Davidson (2005) and Watson (2005) give diagnostic characters for similar species, Chrysomphalus bifasciculatus and Ch. dictyospermi, which can be safely distinguished from Ch. aonidum by morphological characters on the adult female body. The main diagnostic character is the number of marginal clusters of the prepygidial macroducts (Fig. 3, 4). Chrysomphalus aonidum has one marginal cluster on each side of the pygidial segment 2 while Ch. bifasciculatus has two groups on each side of the pygidial segment 2 and 3. Marginal clusters are completely missing in Chrysomphalus dictyospermi.

\section{Biology}

Schweig \& Grunberg (1936), Fasulo \& Brooks (1993), Koteja (1990), MacFarlane (1999), Waterhouse \& Sands (2001), Miller \& Davidson (2005), Watson (2005) and Ben-Dov (2012) provide details on the biology of Chrysomphalus aonidum. It is oviparous, bisexual, occasionally parthenogenetic. Its development depends on temperature, lasting 40-55 days in summer and about 170 days in winter, and sex (40-180 days in females, 26-160 days in males). Sex-ratio is 0.82:1 males:females (Nur, 1990; Santos \& Gravena, 2005). Eggs are pale yellow, oval, laid in groups of approximately ten eggs under the scale cover. The number of eggs laid by a single female depends on the host plant (Rosen \& DeBach, 1978), ranging between 19-300, with 145 eggs in average. On citrus, a significantly higher fertility was observed on fruits than on leaves. Hatching occurs a few hours up to ten days after the oviposition, 


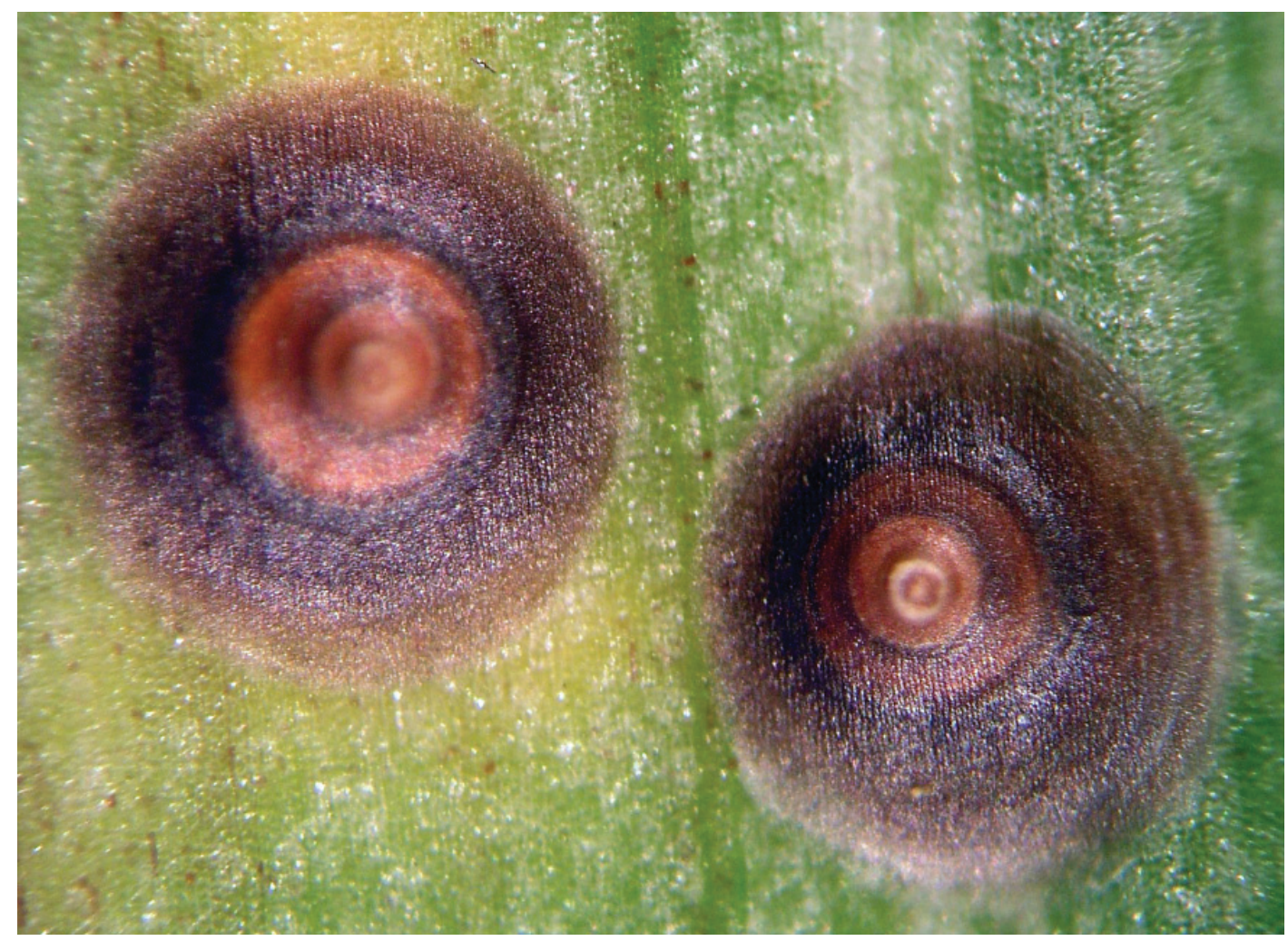

1: Chrysomphalus aonidum-female scales

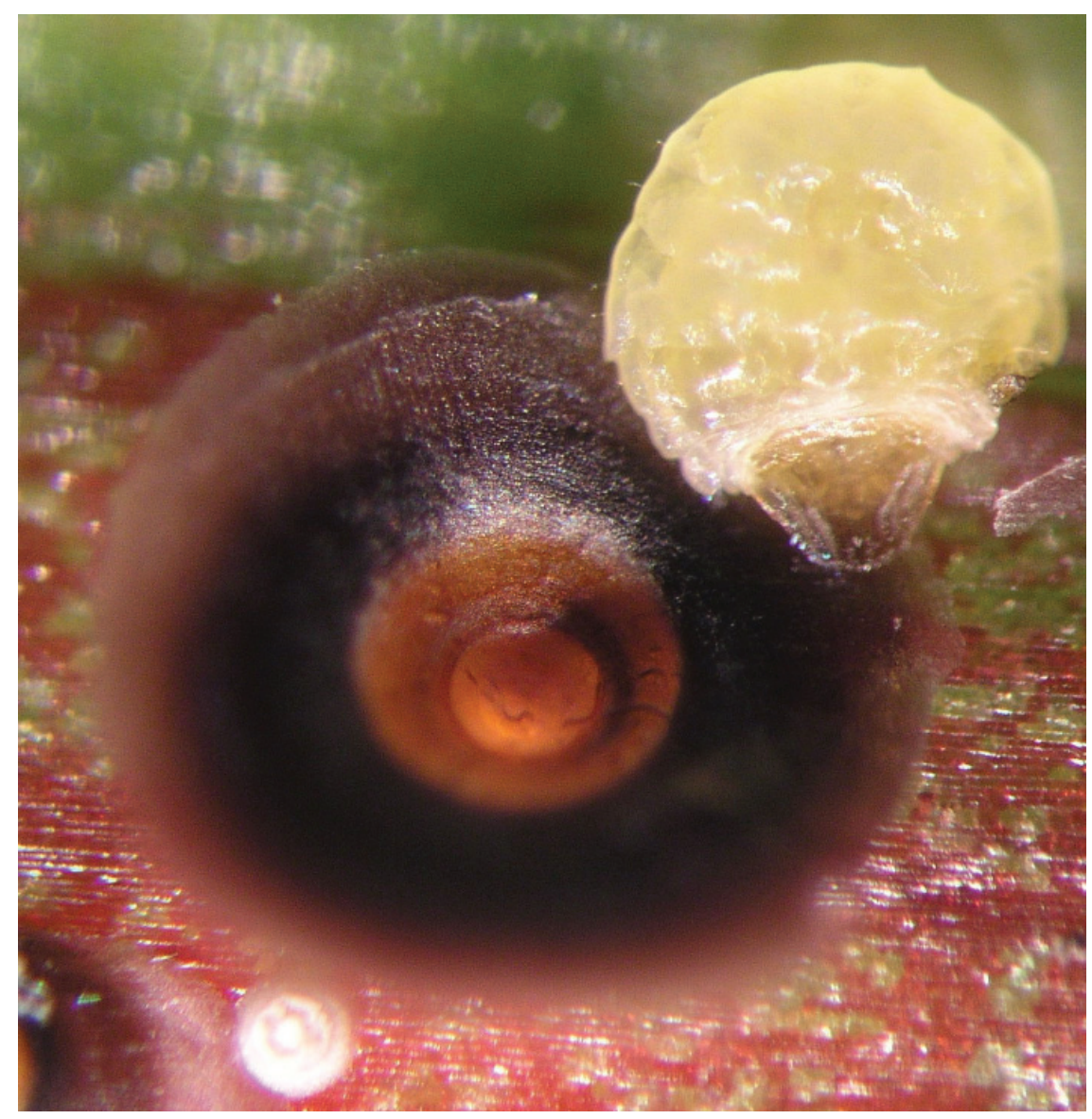

2: Chrysomphalus aonidum - exposed adult female and its scale 


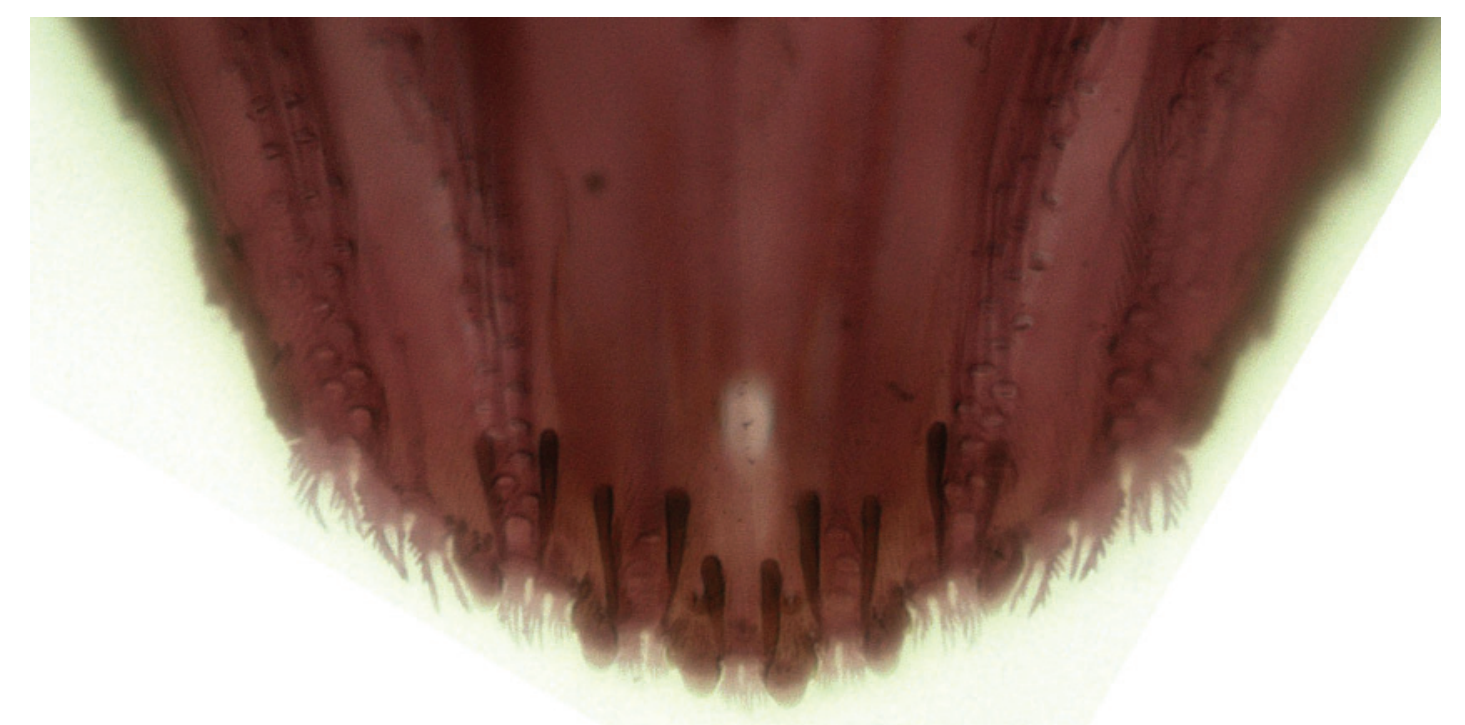

3: Chrysomphalus aonidum - detail of the female pygidial margin

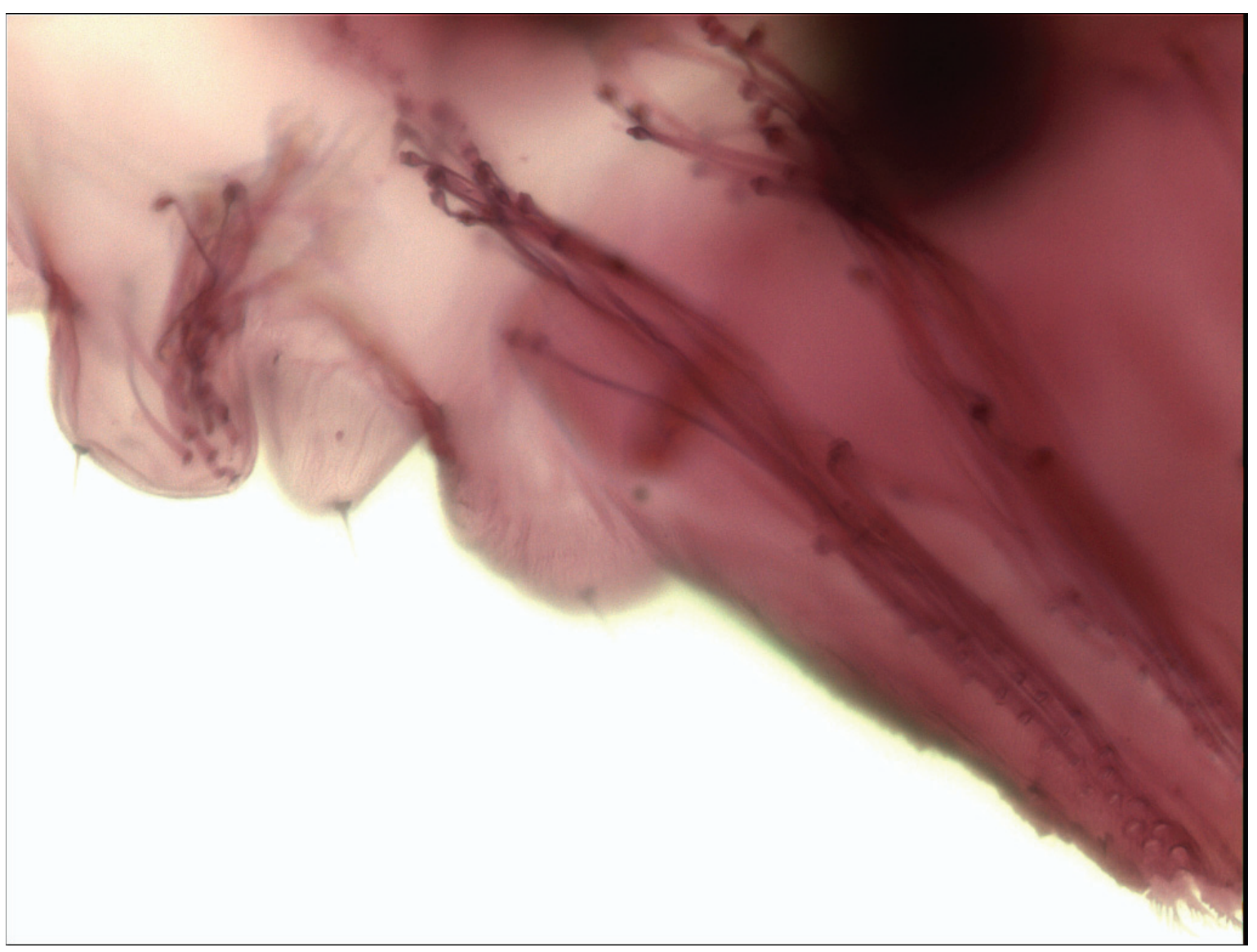

4: Chrysomphalus aonidum - a marginal cluster of female prepygidial macroducts; all photographs by I. Hlavjenková

depending on the abiotic environmental factors. Santos \& Gravena (2005) reported an average duration of the egg stage as 8.1 days under $25^{\circ} \mathrm{C}$, $70 \%$ humidity and 12 -hours light period. According to some other authors, the larvae hatch 24-48 hours after the oviposition. Fertility and female life expectancy are also affected by relative humidity and temperature. Optimum conditions are 70\% humidity and average daily temperature in the range of $23-27^{\circ} \mathrm{C}$ when the survival rate from egg to maturity is $62.7 \%$ and the adult life expectancy is 62 days (Santos \& Gravena, 2005).

Females are paurometabolous, males parametabolous. The larval development includes two instars 
in females and four instars (the last two resting) in males. Only the first larval instar (crawler) is vagile in both sexes, with the ability to spread and find a host plant. The larvae are easily dispersed by wind, other insects and human activities. Young larvae can be found along the central rib and veins on leaves or in fruit depressions. After having found a suitable place for feeding, crawlers start secreting a characteristic waxy coating. The second female instar has reduced legs. The females mature by neoteny and start oviposition about 43 days after the settlement of crawlers.

The number of generations depends on the host plant species, the location of the plant and environmental conditions. Miller \& Davidson (2005) reported 3-6 generations annually outdoors under subtropical climate. In China and Palestine 3-4 generations per year were observed, in Australia 2-6 (Waterhouse \& Sands, 2001; Miller \& Davidson, 2005; Schweig \& Grunberg, 1936), in Florida and California 6 (Fasulo \& Brooks, 1993; Watson, 2005), and in Spain 3-4 (Soto et al., 2008). In heated greenhouses and tropical areas, the development is continuous throughout the year and generations overlap.

\section{Ecological requirements and host plants}

Chrysomphalus aonidum prefers relatively humid conditions, it does not tolerate frost; its abundance is reduced by heavy rain and increases during dry weather (Schweig \& Grunberg, 1936; Watson, 2005). Plants can be infested in their vegetative growth, flowering, fruit production, as well as post-harvest stages (Watson, 2005). Ch. aonidum prefers fruits and leaves but it occasionally develops also on green shoots (Schweig \& Grunberg, 1936; Hill, 1983; Fasulo \& Brooks, 1993; Miller \& Davidson, 2005; Watson, 2005; Hill, 2008; Ben-Dov, 2012). It sucks out the content of parenchyma cells (Watson, 2005). Male larvae are more tolerant to lower humidity. They can be found on the upper side of leaves (Hill 1983; Miller \& Davidson, 2005; Borrás et al., 2006; Hill, 2008; Soto et al., 2008). During the months with the highest sums of temperatures, there are three times more individuals on fruits than on leaves (Miller \& Davidson, 2005). Leaves near the heavily infested fruits may be relatively free of infestation (Fasulo \& Brooks, 1993).

Chrysomphalus aonidum is a widely polyphagous species that attacks both cultivated and naturally growing monocotyledonous and dicotyledonous plants. The species has been detected on 192 genera of 77 unrelated families, including crops, ornamental plants and forest trees (Borchsenius, 1966; Claps \& Teran, 2001; Albuquerque et al., 2002; Miller \& Davidson, 2005; Watson, 2005; French, 2006). The real host range is probably even wider. In the laboratory Ch. aonidum can be kept on Citrulus spp., Solanum tuberosum, Cucurbita pepo, C. maxima, or C. moschata (Bedford, 1989; Stahas \& Kozar, 2005; Andrade et al., 2008).

\section{Origin and distribution}

Chrysomphalus aonidum probably originates in tropical south-eastern Asia (Gill, 1997; Miller \& Davidson, 2005). It has been introduced into most tropical and subtropical areas of the world including North and South America, tropical Africa, Australia, Pacific Islands, the Mediterranean, and the Far East (Miller \& Davidson, 2005; Stahas \& Kozar, 2005, Culik et al., 2008, Ben-Dov, 2012). It has become stabilized outdoor in southern Europe (Pellizzari \& Germain, 2010). In northern regions and central Europe, however, it has been recorded only in greenhouses (Kosztarab \& Kozar, 1988; Watson, 2005; Miller \& Davidson, 2005; Pellizzari \& Germain, 2010). Its worldwide distribution is also shown in maps by CABI (1988) and Miller \& Davidson (2005).

In Europe, Ch. aonidum has been found in Croatia, Cyprus, Greece, Malta, Romania, Serbia, Spain (CABI, 1988), Belgium, Bulgaria, Denmark, France, Germany, Great Britain, Hungary, Italy, Madeira, Morocco, Netherlands and Poland (Ben-Dov, 2012; Burckhardt, 2011; Watson, 2005), and, since 2008, also in Slovenia (Beloglavec et al., 2009). In Portugal, according to Pellizzari \& Germain (2010) this species was eradicated.

\section{Economic importance and host plant protection possibilities}

The species has spread in the world in connection with the cultivation of citrus crops. On citrus, chlorotic spots are formed around the suction points on leaves and fruits. Heavy infestation causes stunting of corresponding plant parts or leads to their litter, citrus fruits become deformed. Woody plants infested for long time wilt, young shoots die. Miller \& Davidson (1990) consider Ch. aonidum as a serious pest of global importance. Beardsley \& Gonzales (1975) rank it among the 43 economically important Diaspididae pests. Pellizzari \& Germain (2010) report Ch. aonidum as one of the ten widely found Diaspididae on citrus in Europe. In addition to citrus crops, it causes economically significant damage to coconut palms, date palms, olive trees, cinnamon, mango, banana, avocado, eucalyptus, guava, grape, papaya and tea in the world (Miller \& Davidson, 1990; Fasulo \& Brooks, 1993; Waterhouse, 1997; MacFarlane, 1999; Waterhouse \& Sands, 2001; Watson, 2005).

In Italy, Ch. aonidum was first registered on plants of Dracaena sp. and Kentia sp. in greenhouses. It has been acclimatized on outdoor plants of the genus Citrus in Calabria since 2006 (Pellizzari \& Vacante, 2007). In 2000 it was recorded in Athens in Greece on the genus Dracaena and it is considered there as an occasional citrus pest because of a difficult acclimatization (Stahas \& Kozar, 2005). To the Netherlands, the species was introduced on plants of Dracaena reflexa var. angustifolia from Costa Rica and Honduras (Jansen, 2004). Recently Ch. aonidum has been recorded as a new pest in greenhouses in 
Hungary (Reiderne \& Kozar, 1994) and added to the quarantine organisms list (Burger \& Ulenberg, 1990). In Poland (Skierniwice), it was observed on ornamental plants of Dracaena reflexa var. angustifolia and D. deremensis in greenhouses in 2004-2006 (Łabanowski, 2009). The first record from Slovenia dates back to 2008; Ch. aonidum was found in a shopping centre on plants of Dracaena reflexa var. angustifolia from the Netherlands (Beloglavec et al., 2009). The species causes more or less important aesthetic damage on ornamental plants which is difficult to evaluate economically.

The wide host range makes it difficult to control Ch. aonidum using insecticides. After reducing its population density, a repeated attack often follows. In cases of repeated attacks Ripa \& Larral (2008) suggest a sulphur insecticide application. Melton \& Shives (1998) applied dimethoate and kinopren to control Ch. aonidum. The insecticides are often effective only after frequent applications which, however, significantly reduce natural enemies of $\mathrm{Ch}$. aonidum (Fasulo \& Brooks, 1993). The latter include 22 parasitoids and 14 predators which can act as biological control. Among them, Hymenoptera prevail, particularly the ectoparasitic Aphytis holoxanthus (DeBach, 1960) and endoparasitic Pteroptrix smithi (Compere, 1953) (Aphelinidae) are often used. Steinberg et al. (1986) argue that both parasitoids together control Ch. aonidum effectively during the year. Cilliers (1971) cited Comperiella bifasciata Howard, 1906 (Encyrtidae) as parasitoid, which was tested as a pest antagonist in laboratory. Later it failed in competition with $A$. holoxanthus in citrus orchards. Aphytis chrysomphali (Mercet, 1912) was recorded as a natural enemy on citrus trees in Spain. As a result of parasitation, females of Ch. aonidum are not fertilized and the next generation abundance is reduced (Schweig \& Grunberg, 1936). In Greece, Ch. donidum was kept on cucumbers and potatoes in order to study the coccinellid predator Rhyzobius lophanthae (Blaisdell, 1892) and its morphology and biology. Santos \& Gravena (2005) investigated the ability predation of the coccinellid Coccidophilus citricola Bréthes, 1905. Evaluation of these antagonists effectiveness has not been available yet.

\section{CONCLUSIONS}

The occurrence of Chrysomphalus aonidum on ornamental plants in the Czech Republic is reported here for the first time. This species had been occasionally imported into the country on citrus fruits in the past (Zahradník, 1959). Plants imported from abroad and offered in garden centres can be considered as source of this pest. A similar way of the pest introduction has been detected in other European countries (Italy, Netherlands, Poland, Greece, and Slovenia).

Trading with potted ornamental plants and extending citrus growing areas generally contribute to the spread of Ch. aonidum. In connection with transportation of plants and other materials, Ch. aonidum can be introduced also to northern areas where it can become a significant pest of ornamental plants in greenhouses or households. Low winter temperatures are a limiting factor in the species acclimatization. Seasons, typical of temperate conditions, make it difficult for Ch. aonidum to acclimatize outdoor. In the Czech Republic, Ch. aonidum can thus become a pest of indoor and greenhouse plants only.

\section{SUMMARY}

First records of the alien species Chrysomphalus aonidum (Linnaeus, 1758) (Hemiptera: Coccoidea: Diaspididae) on ornamental plants in the Czech Republic are described. The species was registered in 2008-2010, on plants of Dracaena reflexa var. angustifolia, in garden centres of northern and southern Moravia (Opava, Ostrava, Brno) and also found on the same plants in households (Brno, Ostrava). Ch. aonidum had been occasionally introduced into the Czech Republic with citrus fruits formerly, but it had not been found on cultivated plants.

The number of generations of Ch.aonidum depends on the host plant species, the location of the plant and environmental conditions; 2-6 generations per year were observed outdoor while in heated greenhouses and tropical areas the development is continuous throughout the year and generations overlap. Chrysomphalus aonidum is a widely polyphagous species that attacks both ornamental and naturally growing monocotyledonous and dicotyledonous plants. It has been detected on 192 genera of 77 unrelated families, including crops, ornamental plants and forest trees. Chrysomphalus aonidum probably originates in tropical south-eastern Asia. It is widespread outdoor in most tropical and subtropical areas, and stabilized outdoor in southern Europe. In northern regions including central Europe it has been recorded only in greenhouses. The species is widespread in the world in connection with the cultivation of citrus crops. Chlorotic spots are formed around the suction points on leaves and fruits of host plants. Heavy infestation causes stunting of corresponding plant parts or leads to their litter, fruits may become deformed. Woody plants infested for a long time wilt, young shoots die.

The wide host range makes it difficult to control Ch. aonidum using insecticides. After reducing its population density, a repeated attack often follows. Insecticides are thus effective usually only after their frequent application which, however, significantly reduces natural enemies of Ch.aonidum. 


\section{Acknowledgement}

This study was supported by the Research plan No. MSM6215648905 "Biological and technological aspects of sustainability of controlled ecosystems and their adaptability to climate change", which is financed by the Ministry of Education, Youth and Sports of the Czech Republic. We are grateful to Dr. Gillian Watson (Plant Pest Diagnostics Branch, California Department of Food \& Agriculture, Sacramento, USA) for the confirmation of our determination of Ch.aonidum and to Ing. Eva Sapáková for a revision of the English text. We thank also to both reviewers, Mgr. Milena Březíková (State Phytosanitary Administration, Olomouc) and Mgr. Igor Malenovský, Ph.D. (Moravian Museum, Brno) for many valuable corrections and comments.

\section{REFERENCES}

ALBUQUERQUE, DE F. A., PATTARO, F. C., BORGES, L. M., LIMA, R. S. \& ZABIN, A. V., 2002: Insetos associados a cultura da aceroleira (Malpighia glabra L.) na regiao de Maringa, Estado do Parana. Acta Scientiarum, 24: 1245-1249.

ALFORD, D. V., 2002: Pests of Ornamental Trees, Shrubs and Flowers. Manson Publishing, London, $449 \mathrm{pp}$.

ALFORD, D. V., 2007: Pests of Fruit Crops. Manson Publishing, London, 461 pp.

ANDRADE, DE LIMA L., BUSOLI, C. A. \& BARBOSA, C. J., 2008: Temperatura no desenvolvimento e na reproduçăo de cochonilhas criadas sobre abóboras. Ciência Rural, 38: 2419_ 2426.

BEARDSLEY, J. W., GONZALEZ, R. H., 1975: The Biology and Ecology of Armored Scales. Annual Review of Entomology, 20: 47-73.

BEDFORD, E. C. G., 1989: The biological control of the circular purple scale, Chrysomphalus aonidum (L.), on citrus in South Africa. Technical Communication, Department of Agriculture and Water Supply, South Africa, 218: 1-6.

BELOGLAVEC, A. B., LIČEN, R., SELJAK, G., KOSI K. Š.,GRANDO, Z., LEŠNIK, M. \& NIKOLIČ, E. P., 2009: Ugotovljeni novi škodljivi organizmi v letu 2008 pri premeščajnu rastlin iz držav članic Evropske unije ali med pridelavo $\mathrm{v}$ Sloveniji, S. 483-487. In: MAČEK J.: Zbornik predavanj in referatov 9. slovenskega posvetovnaja o varstvu rastlin zmednarodneho udelezbo 4.-5. marec 2009, Nova Gorica. Drušstvo za vastvo rastlin Slovenije-Ljubljana. 494 pp.

BEN-DOV, Y. 2012: ScaleNet, Chrysomphalus. Available online: http://www.sel.barc.usda.gov/catalogs/ diaspidi/ChrysomphalusAll.htm (accessed 24 April 2012).

BŘEZÍKOVĀ, M., 2005: Štítenka Pseudaulacaspis pentagona v České republice. Rostlinolékař, 16(5): 15.

BORCHSENIUS, N. S. (ed.), 1966: A Catalogue of the armoured scale insects (Diapidoidea) of the world. Nauka, Moskva - Leningrad, 449 pp.

BORRÁS, M., SOTO, A. \& GARCÍA-MARIE, F., 2006: Evolución estacional de Chrysomphalus aonidum (L.) (Hemiptera: Diaspididae) y prospección en Valencia. Boletín de Sanidad Vegetal. Plagas, 32: 313324.

BURCKHARDT, D., 2011: Fauna Europaea: Diaspididae. In: Fauna Europaea, version 2.4. Available online: http://www.faunaeur.org/full_ results.php?id=186206 (accessed 10 March 2011)
BURGER, H. C. \& ULENBERG, S. A., 1990: Quarantine problems and procedures. Pp. 313326. In: ROSEN D. (ed.): Armored scale insects, their biology. natural enemies and control. World Crop Pests. Vol. 4B. Elsevier, Amsterdam, 384 pp.

CABI, 1988: CAB International: Distribution maps of plant pests. Chrysomphalus aonidum CAB International, Wallingford, UK. Available online: http://www.cabi.org/ (accessed 26 May 2011).

CILLIERS, C. J., 1971: Observations on circular purple scale Chrysomphalus aonidum (Linn.) and two introduced parasites in Western Transvaal citrus orchards. Entomophaga, 16: 269-284.

CLAPS, L. E. \& TERÁN, A. L., 2001: Diaspididae (Hemiptera: Coccoidea) asociadas a cítricos en la provincia de Tucumán (República Argentina). (Diaspididae (Hemiptera: Coccoidea) associated to citrus plants in Tucumán). Neotropical Entomology, 30: 391-402.

CULIK, M. P., MARTINS, D. S., VENTURA, J. A. \& WOLFF, V. S., 2008: Diaspididae (Hemiptera: Coccoidea) of Espírito Santo, Brazil. Journal of Insect Science, 8: 17-23. Available online: http://www. insectscience.org/8.17. (accessed 10 May 2011).

FASULO, T. R. \& BROOKS, R. F., 1993: Scale pests of Florida citrus. In: Series of the Entomology and Nematology Department, Florida Cooperative Extension Service, Institut of Food and Agricultural Sciences, University of Florida, Gainesville. 8 pp. Available online: http://edis.ifas.ufl.edu/ch059 (accessed 10 May 2011).

FRENCH, B. R., 2006: Insect pests of food plants of Papua New Guinea: a compendium. Food Plants International. 276 pp. Available online: http://www. foodplantsinternational.com/?sec=resources (accessed 15 May 2011).

GILL, R. J., 1997: The scale insects of California. Part 3. The armored scales (Homoptera: Coccoidea: Coccidae). Technical Series in Agricultural Biosystematics and Plant Pathology No. 3. California Department of Food and Agriculture, Sacramento, 307 pp.

HILL, D. S., 1983: Agricultural insect pests of the tropics and their control. Cambridge University Press, New York, $760 \mathrm{pp}$.

HILL, D. S., 2008: Pests of crops in warmer climates and their control. Springer, $704 \mathrm{pp}$.

JANSEN, M. G. M., 2004: An updated list of scale insects (Hemiptera, Coccoidea) from import interceptions and greenhouses in the Netherlands. Proceeding of the $X$ International Symposium on Scale Insect Studies. Adana, Turkey, 147-165. 
KOSZTARAB, M. \& KOZÁR, F., 1988: Scale insects of Central Europe. Springer, London, 455 pp.

KOTEJA, J., 1990: 1.3.1. Embryonic development; ovipary and vivipary. 1.3.2. Life history. Pp. 233254. In: ROSEN D. (ed.): Armoured scale insects, their biology, natural enemies and control. Vol. 4A. Elsevier, Amsterdam, 386 pp.

ŁABANOWSKI, G., 2009: Szkodniky roślin ozdobnych zawelekane do polskich szklarn. (Pests of ornamental plants introduced in polish glasshouses). Progress in Plant Protection, 49: 17141723.

LINDINGER, L., 1912: Die Schieldläuse (Coccidae) Europas, Nordafrikas und Vorderasiens, einschliesslich der Azoren, der Kanaren und Madeiras. Eugen Ulmer, Stutgart, $392 \mathrm{pp}$.

MACFARLANE, R., 1999: Chrysomphalus aonidum. The Horticulture and Food Research institute of New Zeland. Available online: http://ecoport.org/ ep?Arthropod=26069\&entityType $=A R^{* * * *}$ \&ent ityDisplayCategory=full (accessed 15 April 2011).

MARTIN, J. H., 1987: An identification guide to common whitefly pest species of the world (Homoptera: Aleyrodidae). Tropical Pest Management, 33: 298-322.

MELTON, F. M. \& SHIVES, A., 1998: Seasonal occurrence of Florida Red Scale, Chrysomphalus aonidum (L.), and Two-Spotted Spider Mite, Tetranychus urticae Koch, in Manatee County. Proceeding Florida State Horticultural Society, 111: 3738.

MILLER, D. R. \& DAVIDSON, A. J., 1990: Armored Scale Insects as Pests. S. 299-306. In ROSEN D. (ed.): Armored scale insects: their biology, natural enemies and control, Vol. 4B. Elsevier, Amsterdam, 384 pp.

MILLER, D. R. \& DAVIDSON, J. A., 2005: Armored scale insect pests of trees and shrubs (Hemiptera: Diaspididae). Cornell University Press, New York, $442 \mathrm{pp}$.

MILLER, F., 1956: Zemédélská entomologie. ČSAV, Praha, 1057 pp.

NUR, U., 1990: 1.2.1 Chromosomes, sex-ratios, and sex determination. Pp. 179-190. In: ROSEN, D. (ed.): Armoured scale insects, theirbiology, naturalenemies and control. Vol. 4A. World Crop Pests. Elsevier, Amsterdam, 386 pp.

PELLIZZARI, G. \& GERMAIN, J. F., 2010: Scales (Hemiptera, Superfamily Coccoidea). Pp. 475510. In: ROQUES A. (ed.), 2010: Alien terrestrial arthropods of Europe. BioRisk 4(1), 555 pp.

PELLIZZARI, G. \& VACANTE, V., 2007: Una nuova cocciniglia sugli agrumi in Italia: il Chrysomphalus aonidum (Linnaeus) (Hemiptera: Diaspididae). Informatore Fitopatologico, 57: 45-47.

PRUNER L. \& MÍKA P., 1996: List of settlements in the Czech Republic with associated map field codes for faunistic grid mapping system. Klapalekiana, Supplement 32: 1-115.

REIDERNE, S. K. \& KOZÁR, F., 1994: Recently appeared scale insect species (Homoptera, Coccoidea, Diaspididae) on glasshouse ornamentals in Hungary. Novenyvedelem, 30: 423427 (In Hungarian, English abstract).

RIPA, R. \& LARRAL, P., 2008: Manejo de plagas en paltos y cítricos. Colección Libros Inia 23. Instituto de investigaciones agropecuaris, Chile, $397 \mathrm{pp}$.

ROSEN, D. \& DEBACH, P., 1978: Diaspididae. Pp. 78-128. In: CLAUSENC P. (ed.): Introduced parasites and predators of arthropod pests and weeds: a world review. United States Department of Agriculture, Agricultural Handbook, 545 pp.

SANTOS, A. C. DOS \& GRAVENA, S., 2005: Aspectos biológicos de Coccidiophilus citricola (Coleoptera, Coccinellidae) sobre Aspidiotus nerii e Chrysomphalus aonidum (Homoptera, Diaspididae). Ciência Rural, 35: 6-9.

SCHMUTTERER, H., 1959: Schildläuse oder Coccoidea. I. Deckelschildläuse oder Diaspididae. Pp. 57-59. In: DAHL M. \& BISCHOFF H.: Die Tierwelt Deutschlands und der angrenzenden Meeresteile, Teil 45. Gustav Fischer Verlag, Jena, 260 pp.

SCHWEIG, C.\& GRUNBERG, A., 1936. The problem of black scale (Chrysomphalus ficus Ashm.) in Palestine. Bulletin of Entomological Research, 27: 677713.

SOTO, A., BORRÁS, M., VERCHER, R. \& GARCÍAMARÍ, F., 2008: Chrysomphalus aonidum (L.) (Hemiptera: Diaspididae) in Spain. Studies on its biology and population dynamics. In: Proceedings of the meeting at Catania (Italy), 2007. IOBC/wprs Bulletin 38, 345 pp.

STAHAS, G. J. \& KOZÁR, F., 2005: Chrysomphalus aonidum as a pest of citrus in Greece. Entomologia Hellenica, 16: 16-2.

STEINBERG, S., PODOLER, H. \& ROSEN, D., 1986: Biological control of the Florida red scale, Chrysomphalus aonidum, in Israel by two parasite species: current status in the coastal plain. Phytoparasitica, 14:199-204.

ŠEFROVÁ, H. \& LAŠTU゚VKA, Z., 2005: Catalogue of alien animal species in the Czech Republic. Acta Universitatis Agriculturae et Silviculturae Mendeleianae Brunnensis, 53 (4): 151-170.

WATERHOUSE, D. F., 1997: The major invertebrate pests and weeds of agriculture and plantation forestry in the southern and western Pacific. Canberra, Australia, $99 \mathrm{pp}$.

WATERHOUSE, D. F. \& SANDS, D. P. A., 2001: Classical biological control of arthropods in Australia. Canberra, Australia, 560 pp.

WATSON, G. W., 2005: Arthropods of Economic Importance Diaspididae of the World. World Biodiversity Database 2005. Available online: http://nlbif.eti.uva.nl/bis/diaspididae.php?selec ted=beschrijving\&menuentry=soorten\&id=102 (accessed 12 July 2010)

ZAHRADNÍK, J., 1959: Červci-Coccinea.Pp. 527-552, 614-716. In: KRATOCHVÍL J. (ed.): Klič zvíreny ČSR, III. ČSAV, Praha, 870 pp.

ZAHRADNÍK, J., 1968: Schildläuse unserer Gewächshäuser. Die neue Brehm-Bücherei. A. Ziensen Verlag, Wittenberg Lutherstadt, 44 pp. 
ZAHRADNÍK J., 1977: Aleyrodinea - Coccinea. In: DLABOLA J. (ed.): Check List Enumeratio Insectorum Bohemoslovakiae. Acta Faunistica Entomologicae Musei Nationalis Pragae, Supplement 4: $117-122$.
ZAHRADNÍK J., 1990: Die Schildläuse (Coccinea) auf Gewächshaus- und Zimmerpflanzen in den Tschechischen Ländern. Acta Universitatis Carolinae Biologica, 34: 1-160.

Ing. Iva Hlavjenková, Česká inspekce životního prostředí, Valchařská 15, 70000 Ostrava, Česká republika, doc. Ing. Hana Šefrová, Ph.D., Ústav pěstování, šlechtění rostlin a rostlinolékařství, Mendelova univerzita v Brně, Zemědělská 1, 61300 Brno, Česká republika, e-mail: IvaHlavjenkova@seznam.cz, sefrova@mendelu. 
